\title{
Studies of pituitary function in lactating ewes
}

\author{
B. J. Restall, R. D. Kearins* and B. G. Starr \\ New South Wales Department of Agriculture, P.O. Box 239, Blacktown, New South Wales, \\ and ${ }^{*}$ New South Wales Department of Agriculture, Cobar, \\ New South Wales, Australia
}

\begin{abstract}
Summary. The release of $\mathrm{LH}$ from the pituitary of lactating ewes was studied. In Exp. 1 , ewes were injected with $50 \mu \mathrm{g}$ oestradiol benzoate (OB), $2.0 \mathrm{mg}$ testosterone propionate (TP) or oil only (control) on Days 5, 10 or 20 after lambing. LH was measured in peripheral plasma samples obtained $20-38 \mathrm{~h}$ after treatment, and ovulations were recorded. The number of ewes in which an LH release was detected, and the amount released, declined between Days 5 and 20 after OB treatment but increased after TP treatment. The releases of LH were not always accompanied by ovulation and the incidence of ovulation was higher in ewes treated with TP. In Exp. 2, lactating ewes were injected with 1 or 5 (at 2-h intervals) doses of $50 \mu \mathrm{g} \mathrm{Gn-RH,} \mathrm{on} \mathrm{Days} 12$ or 25 after lambing. $\mathrm{LH}$ was measured in peripheral plasma samples collected every $2 \mathrm{~h}$ for 10 $\mathrm{h}$ and every $3 \mathrm{~h}$ for a further $70 \mathrm{~h}$. Release of $\mathrm{LH}$ occurred in all ewes, the amount being greater in ewes receiving multiple injections and in ewes treated on Day 25 . The incidence of ovulation was higher after treatment on Day 25. Multiple injections of Gn-RH appeared to reduce the incidence of abnormal corpora lutea.
\end{abstract}

\section{Introduction}

When lactating ewes are naturally or artificially bred in the first 40 days after lambing, variable responses of oestrus, ovulation and fertility have been reported (see Foote, 1968; Hunter, 1968; Colas, Brice, Courot \& Cottier, 1971 ; Restall, Kearins, Herdegen \& Carberry, 1977). The endocrinological and physiological state of such ewes is poorly understood (Hunter, 1968). Pelletier \& Thimonier (1973) concluded that the preovulatory release of $\mathrm{LH}$ was reduced during lactation in the ewe. Chamley et al. (1974a) suggested that the pituitary of lactating ewes was either depleted of LH and FSH or refractory to releasing hormone for at least 3 weeks after lambing, but Restall, Radford \& Wallace (1972) were able to obtain release of LH in lactating ewes in the first 2 weeks after lambing. The level of LH in peripheral plasma gradually increases after lambing, and season and early weaning have been shown to affect the recovery of pituitary function (Restall \& Starr, 1977).

Because of the importance of developing methods for inducing fertile matings in sheep, we investigated whether the pituitary of the lactating ewe can release LH in sufficient quantity to cause ovulation.

\section{Materials and Methods}

\section{Experiments}

Two experiments were conducted at the Agricultural Research Station, Condobolin, in the Central Western area of New South Wales.

In Exp. 1, the release of $\mathrm{LH}$ in response to treatment with steroids at various times after lambing was examined. Mature Merino ewes lambing during May 1972 were randomly assigned to treatments (5/group) in a $3 \times 3$ factorial experiment. For Factor 1 , the steroid treatments, given i.m., were (1) $50 \mu$ g oestradiol benzoate in $1 \mathrm{ml}$ peanut oil; (b) $2.0 \mathrm{mg}$ testosterone propionate in $1 \mathrm{ml}$ peanut oil; (c) $1 \mathrm{ml}$ peanut oil (control). For Factor 2, the time of treatment after lambing was investigated for Days 5, 10 and 20. Peripheral plasma samples were obtained from all ewes by venepuncture at 20, 23, 
$26,29,32,35$ and $28 \mathrm{~h}$ after treatment as a preliminary experiment had indicated that lactating ewes responded during this period. Ovarian inspections were performed via midventral laparotomy 5 days after steroid treatment and recent ovulations were noted and estimates made of their age (Restall, 1964).

In Exp. 2, the effect of single or multiple injections of a gonadotrophin-releasing hormone (Gn-RH: Abbott) were investigated at two times after lambing. Mature Border Leicester $\times$ Merino and Dorset Horn $\times$ Merino ewes lambing in September 1973 were used in a $3 \times 2$ factorial experiment. For Factor 1, the $3 \mathrm{Gn}-\mathrm{RH}$ treatments were (a) a single s.c. injection of $50 \mu \mathrm{g} \mathrm{Gn}-\mathrm{RH}$; (b) 5 s.c. injections of $50 \mu \mathrm{g} \mathrm{Gn}-\mathrm{RH}$ at 2-h intervals; and (c) no treatment (control). For Factor 2, the times of the treatment after lambing were Days 12 and 25. The two control groups contained 5 ewes, the other groups 10 ewes. Peripheral plasma samples were collected via jugular venepuncture before, at, and $2,4,6$ and $8 \mathrm{~h}$ after Gn-RH injection and thence every $3 \mathrm{~h}$ for a further $70 \mathrm{~h}$. Ovarian inspections were performed 5-6 days after treatment for determination of ovulation and assessment of age of the CL.

\section{Assays}

All plasma samples were stored at $-15^{\circ} \mathrm{C}$ until assayed for LH by the method of Goding $e$ al . (1969). Internal standards were included in all assays and the results were adjusted for inter-assay variations. The LH standard used was equipotent with NIH-LH-S17. Within- and between-assay coefficients of variation were $4-9 \%$ and $8-14 \%$, respectively, and the sensitivity of the assay was approximately $0.5 \mathrm{ng} / \mathrm{ml}$. This sensitivity is sufficient to measure basal $\mathrm{LH}$ levels and the precision is satisfactory for detecting large increases in plasma LH. The amount of LH released was calculated as the area under the plasma LH curves.

Table 1. The mean $\mathrm{LH}$ concentration $(\mathrm{ng} / \mathrm{ml})$ in the peripheral plasma of lactating ewes (5/group) treated with oestradiol benzoate (OB) or testosterone propionate (TP) at various times after lambing

\begin{tabular}{|c|c|c|c|c|c|c|c|c|c|}
\hline \multirow{2}{*}{$\begin{array}{l}\text { Days } \\
\text { after } \\
\text { lambing }\end{array}$} & \multirow{2}{*}{$\begin{array}{l}\text { Treat- } \\
\text { ment }\end{array}$} & \multicolumn{7}{|c|}{ Time after injection (h) } & \multirow{2}{*}{$\begin{array}{c}\text { Mean } \\
\pm \text { S.E.M. }\end{array}$} \\
\hline & & 20 & 23 & 26 & 29 & 32 & 35 & 38 & \\
\hline \multirow[t]{4}{*}{5} & Control & $3 \cdot 08$ & $2 \cdot 64$ & $3 \cdot 02$ & $2 \cdot 60$ & $3 \cdot 28$ & 3.88 & $3 \cdot 68$ & $3 \cdot 17 \pm 0 \cdot 18$ \\
\hline & $\mathrm{OB}$ & 5.88 & 22.04 & $35 \cdot 12$ & $27 \cdot 90$ & $9 \cdot 62$ & $4 \cdot 24$ & $3 \cdot 52$ & $15 \cdot 47 \pm 3.78$ \\
\hline & TP & $5 \cdot 00$ & $4 \cdot 32$ & $14 \cdot 36$ & $9 \cdot 12$ & $7 \cdot 36$ & $4 \cdot 48$ & 2.58 & $6.60 \pm 1.20$ \\
\hline & Control & $3 \cdot 28$ & 2.74 & $3 \cdot 18$ & 2.54 & 4.88 & $2 \cdot 12$ & $3 \cdot 24$ & $3 \cdot 14 \pm 0 \cdot 3 c$ \\
\hline \multirow[t]{2}{*}{10} & OB & $42 \cdot 78$ & $17 \cdot 70$ & $28 \cdot 26$ & $9 \cdot 48$ & $4 \cdot 90$ & $3 \cdot 16$ & $3 \cdot 34$ & $15 \cdot 15 \pm 4 \cdot 29$ \\
\hline & TP & $34 \cdot 36$ & $32 \cdot 22$ & $39 \cdot 12$ & 29.80 & $15 \cdot 32$ & 5.92 & 3.72 & $22.92 \pm 4.85$ \\
\hline \multirow[t]{3}{*}{20} & Control & 3.84 & 3.54 & $3 \cdot 48$ & $2 \cdot 70$ & $4 \cdot 84$ & $2 \cdot 66$ & $3 \cdot 10$ & $3.45 \pm 0.28$ \\
\hline & $\mathrm{OB}$ & 29.00 & 8.04 & $5 \cdot 30$ & 3.80 & 3.06 & 2.94 & 2.08 & $7 \cdot 75 \pm 2 \cdot 23$ \\
\hline & TP & $42 \cdot 28$ & $60 \cdot 78$ & $30 \cdot 86$ & $11 \cdot 10$ & $11 \cdot 32$ & $8 \cdot 32$ & $5 \cdot 24$ & $24 \cdot 27 \pm 5 \cdot 52$ \\
\hline
\end{tabular}

Summary of the analysis of variance

\begin{tabular}{lrcc}
\hline \multicolumn{1}{c}{ Source of variation } & d.f. & Mean square & Variance ratio \\
\hline Between treatments (A) & 2 & $5852 \cdot 32$ & $16 \cdot 20^{* *}$ \\
Between days (B) & 2 & $807 \cdot 18$ & $2 \cdot 23$ \\
A $\times$ B & 4 & 1646.59 & $4 \cdot 55^{* *}$ \\
Between ewes within A $\times$ B (error 2) & 36 & 361.26 & $1 \cdot 23$ \\
Between times after treatment (C) & 6 & $1962 \cdot 10$ & $6.68^{* *}$ \\
C $\times$ A & 12 & 614.94 & $2 \cdot 09$ \\
C $\times$ B & 12 & 519.48 & $1 \cdot 77$ \\
C $\times$ A $\times$ B & 24 & 379.60 & $1 \cdot 29$ \\
Residual (error 1) & 216 & 293.69 & \\
\end{tabular}

$* * P<0.01$. 
Table 2. The mean \pm S.E.M. amount of LH released (in arbitrary units, area under curve) in lactating ewes (no. in parentheses) treated with steroids at various times after lambing

\begin{tabular}{|c|c|c|c|c|}
\hline \multirow[b]{2}{*}{ Treatment } & \multirow{2}{*}{$\begin{array}{l}\text { Evidence of } \\
\text { LH release }\end{array}$} & \multicolumn{3}{|c|}{ Days after lambing } \\
\hline & & 5 & 10 & 20 \\
\hline Control & + & - & - & - \\
\hline & - & $53.5 \pm 1.7(5)$ & $55.2 \pm 5.9(5)$ & $58.4 \pm 6.3(5)$ \\
\hline Oestradiol benzoate & + & $296.9 \pm 31 \cdot 3(5)$ & $271.9 \pm 73.4(4)$ & $126 \cdot 1 \pm 18 \cdot 0(3)$ \\
\hline$(50 \mu \mathrm{g})$ & - & $=$ & $59.4 \quad$ (1) & $54.6 \pm 20.5(2)$ \\
\hline Testosterone & + & $171 \cdot 9 \pm 50.4(3)$ & $470 \cdot 2 \pm 70 \cdot 9(4)$ & $386.9 \pm 75.7(5)$ \\
\hline propionate $(2 \mathrm{mg})$ & - & $72.4 \pm 0.5(2)$ & 73.9 & - \\
\hline
\end{tabular}

\section{Results}

\section{Experiment 1}

The mean concentration of plasma LH in the ewes in each group is shown in Table 1. There were significant differences between the treatments and between times after treatment, the steroids resulting in elevations in $\mathrm{LH}$ concentrations between 20 and $30 \mathrm{~h}$ after treatment. Not all ewes given steroids had an $\mathrm{LH}$ release in the period studied, and there was a significant 'treatment $\times$ day of treatment' interaction, which was also significant for the amount of LH released $(P<0.01$; Table 2$)$. The number of ewes in which an LH release was detected after treatment with oestradiol benzoate declined from 5 ewes on Day 5 to 3 ewes on Day 20 while the reverse was evident for ewes treated with testosterone propionate. The amount of $\mathrm{LH}$ released declined with time after lambing in response to the oestradiol and increased up to Day 10 and was still at a high level on Day 20 after lambing in ewes receiving testosterone.

Elevations in plasma $\mathrm{LH}$ concentration were not always accompanied by ovulation: of the 12 ewes releasing $\mathrm{LH}$ in response to oestradiol benzoate, $0 / 5,1 / 4$ and $1 / 3$ ovulated on Days 5,10 and 20,

Table 3. Incidence of ovulation and mean \pm S.E. M. amount of LH released (in arbitrary units, area under curve) for the first $14 \mathrm{~h}$ after injection of $\mathrm{Gn}-\mathrm{RH}$ in lactating ewes treated on Days 12 or 25 after lambing

\begin{tabular}{|c|c|c|c|c|c|c|c|c|}
\hline \multirow[b]{4}{*}{ Treatment } & \multicolumn{8}{|c|}{ Days after lambing } \\
\hline & \multicolumn{4}{|c|}{12} & \multicolumn{4}{|c|}{25} \\
\hline & \multirow{2}{*}{$\begin{array}{c}\text { No. of } \\
\text { ewes }\end{array}$} & \multirow{2}{*}{$\stackrel{\text { LH }}{\text { released }}$} & \multicolumn{2}{|c|}{ No. of ovulations } & \multirow{2}{*}{$\begin{array}{c}\text { No. of } \\
\text { ewes }\end{array}$} & \multirow{2}{*}{$\underset{\text { released }}{\mathbf{L H}}$} & \multicolumn{2}{|c|}{ No. of ovulations } \\
\hline & & & Normal & Abnormal & & & Normal & Abnormal \\
\hline $1 \times 50 \mu \mathrm{g} \mathrm{Gn}-\mathrm{RH}$ & 10 & $237 \cdot 0 \pm 40 \cdot 5$ & 5 & - & 10 & $300 \cdot 0 \pm 40 \cdot 5$ & 4 & 4 \\
\hline $\begin{array}{c}5 \times 50 \mu \mathrm{g} \mathrm{Gn}-\mathrm{RH} \\
\text { at } 2 \text {-h intervals }\end{array}$ & 10 & $343 \cdot 0 \pm 62 \cdot 3$ & 5 & - & 10 & $484 \cdot 0 \pm 75 \cdot 4$ & 9 & 1 \\
\hline None (control) & 5 & $8 \cdot 6 \pm 1 \cdot 5$ & 0 & 一 & 5 & $18 \cdot 0 \pm 3 \cdot 1$ & 0 & 0 \\
\hline
\end{tabular}

Summary of analysis of variance

\begin{tabular}{lrrc}
\hline \multicolumn{1}{c}{ Source of variation } & d.f. & Mean square & Variance ratio \\
\hline Between treatments & 2 & 82016.65 & $53.67^{* *}$ \\
Between days of treatment & 1 & 7561.50 & $4.95^{*}$ \\
Interaction & 2 & 2202.02 & 1.44 \\
Error & 49 & $1528 \cdot 10$ & \\
\hline & $* P<0.05 ; * * P<0.01$.
\end{tabular}


respectively, and release of $\mathrm{LH}$ in ewes treated with testosterone propionate was followed by ovulation in 1/3 (Day 3), 4/4 (Day 10) and 3/5 (Day 20) ewes.

\section{Experiment 2}

The plasma LH concentrations after treatment with Gn-RH are shown in Text-fig. 1. Release of LH was observed in all treated ewes, the amounts released being greater on Day 25 and after multiple injections of $\mathrm{LH}$ (Table 3). There were no further releases of $\mathrm{LH}$ in the $70 \mathrm{~h}$ following the initial response to the Gn-RH.

The number of ewes ovulating varied but the incidence was higher after treatment on Day 25. Some of the $\mathrm{CL}$ were classed as abnormal, being small and pale with undeveloped rupture points, and their incidence was lower in ewes receiving multiple injections of the Gn-RH (Table 3).
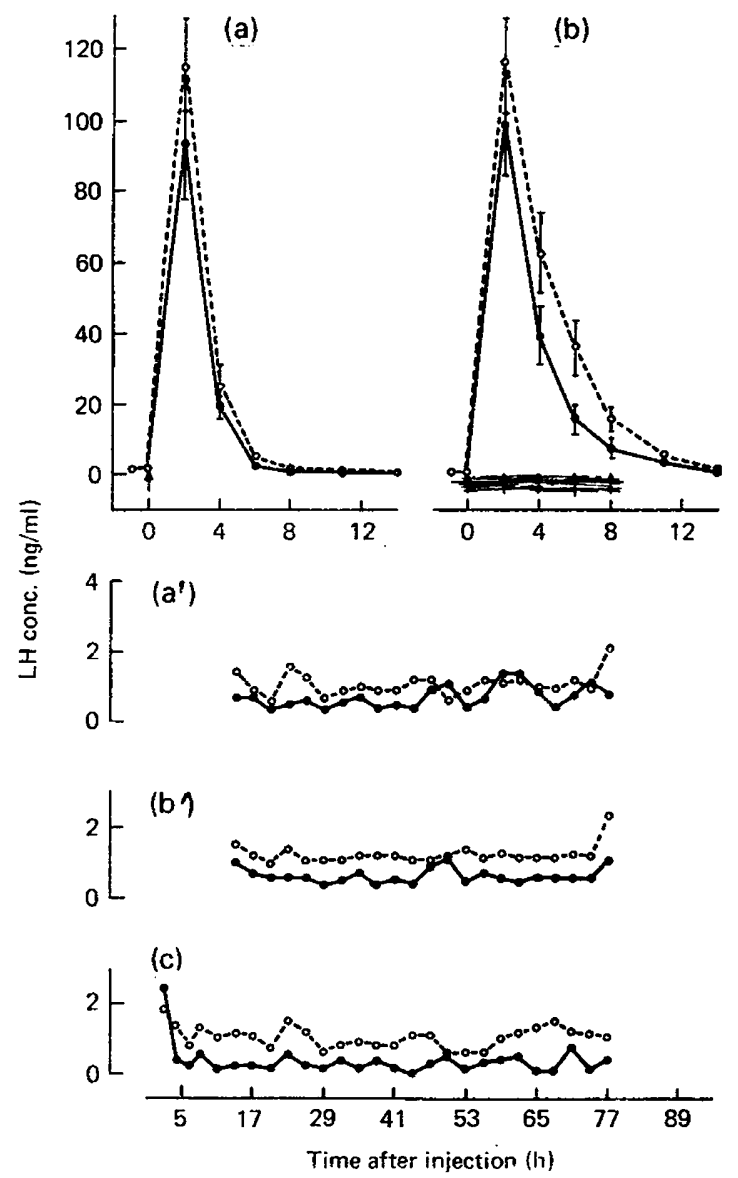

Text-fig. 1. Peripheral mean \pm S.E.M. plasma concentrations of $\mathrm{LH}$ in lactating ewes treated with (a) a single $(50 \mu \mathrm{g})$ or (b) multiple $(5 \times 50 \mu \mathrm{g}, 2$-h intervals) injections of $\mathrm{Gn}-\mathrm{RH}$ at $12(-\longrightarrow)$ or $25(-\ldots-)$ days after lambing. The lower graphs show the basal LH levels in the treated ewes after single $\left(a^{\prime}\right)$ and multiple (b) injections of Gn-RH from 15-77 h after Gn-RH treatment and in the untreated ewes (c). The results are for 10 treated ewes and 5 control ewes per group.

\section{Discussion}

These experiments show that the sheep pituitary is capable of releasing significant amounts of $\mathbf{L H}$ as early as 5 days after lambing, although Chamley et al. $(1974$ a,b) did not find significant LH or FSH 
releases in lactating ewes infused with Gn-RH at parturition and 3 weeks after lambing. This disparity may be due to either the low dose of Gn-RH infused $(1.5 \mu \mathrm{g} / \mathrm{h})$ or the mode of administration used by Chamley et al. but is clearly not because the pituitary is depleted of LH or refractory to Gn-RH. The pituitary content of LH is low at parturition but does increase in the following 3 weeks (O'Reilly \& Dziuk, 1973; Jaume cited by Chamley et al., 1973), and these stores of LH are apparently sufficient for the significant releases reported here.

The reduction in the occurrence and amount of $\mathrm{LH}$ release after oestradiol benzoate treatment 20 days after lambing may be due to responses occurring before sampling began. The preliminary study which suggested the $20-38 \mathrm{~h}$ sampling period (Restall et al., 1972) did not examine ewes beyond 11 days after lambing. In the present study plasma LH levels in 3 ewes were already elevated when sampling began, accounting in part for the apparently reduced release. We think it more likely that there has been a change in the time of response between 5 and 20 days after lambing rather than an absence of response. This implies a change in some part of the hypothalamo-hypophysial releasing mechanism, as yet unknown (McGuire \& Lisk, 1969; Radford \& Wallace, 1974).

A similar change in the time of $\mathrm{LH}$ response, in the reverse direction, occurred with testosterone treatment. Radford \& Wallace (1971) showed that large doses of testosterone propionate caused ovarian stimulation and our results, with similarly large doses, suggest that this is due to release of LH. Testosterone may act directly on the pituitary (Sar \& Stumpf, 1973) or a small part may be aromatized to oestrogen (McDonald, Grodin \& Siiteri, 1971). In the latter case, a change in the rate of aromatization between Days 5 and 20, together with a change in the time of response to oestrogen, would account for the interaction between the effects of oestradiol and testosterone observed here.

The releases of $\mathrm{LH}$ observed in response to $\mathrm{Gn}-\mathrm{RH}$ are in agreement with other studies (Foster \& Crighton, 1973) and are similar to Gn-RH-evoked releases in anoestrous and spayed ewes (Reeves et al., 1972; White, Hedlund, Rippel, Arnold \& Flouret, 1973; Radford \& Wallace, 1974; Symons, Cunningham \& Saba, 1974). The pattern of release of LH was similar on Days 12 and 25 after lambing, but significantly more was released at the later time, indicating a change in pituitary sensitivity to Gn-RH, a change in pituitary content of LH, or increased synthesis. Despite the differences in response to the two steroids, the data from these two experiments indicate that the release mechanism for $\mathrm{LH}$ can function in the lactating ewe and that significant quantities of endogenous LH can be discharged shortly after lambing.

However, ovulation was not always a consequence of the LH releases, especially those after oestradiol treatment. The ovary is capable of responding to gonadotrophin as early as 15 days after lambing (Restall et al., 1977) but oestradiol may have directly altered the ovarian responsiveness in our study. The improved ovulatory response to Gn-RH at 25 days after lambing is not considered to be due to follicle maturation as a result of FSH release by Gn-RH (Reeves et al., 1972; White et al., 1973) because this would be expected to lead to oestrogen secretion and, consequently, to a second ovulating release of $\mathrm{LH}$ and this was not observed. Another explanation is that follicular growth gradually recommences after parturition and, in ewes lambing together, follicular development will be relatively synchronized. With such animals, the ovulatory response would be expected to be more uniform than that observed in anoestrous ewes (Reeves et al., 1972).

The abnormal CL observed after Gn-RH treatment on Day 25 after lambing (Table 3) are apparently similar to those observed by Restall (1971) and Hunter \& Van Aarde (1973). No reasonable explanation of these CL has been advanced, but the ruptured follicle does not appear to luteinize. Multiple injections of Gn-RH, with the consequent significant increase in the amount of LH released, appeared to reduce the incidence of the abnormal CL suggesting that they are associated with a gonadotrophic insufficiency.

We thank Mr N. Ticehurst and Mr N. Grinter for care of the experimental animals; Miss Debbis Blundel for technical assistance; and Dr R. Rippel, Abbott Laboratories, North Chicago, Illinois, U.S.A., for generous donations of Gn-RH. The study was supported by a financial grant from the Australian Wool Corporation. 


\section{References}

Chamley, W.A., Brown, J.M., Cerini, M.E., Cumming, I.A., Goding, J.R., Obst, J.M., Williams, A. \& WiNfIELD, C. (1973) An explanation for the absence of post-parturient ovulation in the ewe. $J$. Reprod. Fert. 32, 334, Abstr.

Chamley, W.A., Findlay, J.K., Jonas, H., Cumming, I.A. \& GoDING, J.R. (1974a) Effect of pregnancy on the FSH response to synthetic gonadotrophinreleasing hormone in ewes. J. Reprod. Fert. 37, 109112.

Chamley, W.A., Findlay, J.K., Cumming, I.A., BUCKMASTER, J.M. \& GODING, J.R. (1974b) Effect of pregnancy on the $\mathrm{LH}$ response to synthetic gonadotrophin-releasing hormone in the ewe. Endocrinology 94, 291-293.

Colas, G., Brice, G., Courot, M. \& Cottier, M. (1971) L'insémination artificielle dans les plans d'intensification de la production ovine. Etat actuel et perspectives. Bull. Tech. Inform. Minist. Agric. 257, 147.

Foster, J.P. \& Crighton, D.B. (1973) Comparison of LH levels in post-partum anoestrous and cycling ewes and the effects of synthetic gonadotrophin-releasing factor. J. Reprod. Fert. 35, 599-560, Abstr.

Foote, W.C. (1968) Control of reproduction with or without hormones. In Physiology and Reproduction in Sheep, Sheep Indust. Develop. Prog. Symp. U.S.D.A.

Goding, J.R., KatT, K.J., Brown, J.M., KaLTENBACH, C.C., Cumming, I.A. \& Mole, B.J. (1969) Radioimmunoassay for ovine luteinizing hormone. Secretion of luteinizing hormone during estrus and following estrogen administration in sheep. Endocrinology 85, 133-142.

HUNTER, G.L. (1968) Increasing the frequency of pregnancy in sheep. II. Artificial control of rebreeding and problems of conception and maintenance of pregnancy during the post-partum period. Anim. Breed. Abstr. 36, 533-553.

HUNTER, G.L. \& VAN AARDE, I.M.R. (1973) Influence of season of lambing on post-partum intervals to ovulation and oestrus in lactating and dry ewes at different nutritional levels. J. Reprod. Fert. 42, 1-8.

McDonald, P.C., Grodin, J.M. \& SiIteri, P.K. (1971) In Gonadal Steroidal Secretion, pp. 158-175 Eds D. T. Baird \& J. A. Strong. Williams \& Wilkins, Baltimore.

MCGuIRE, J.L. \& LISK, R.D. (1969) Localisation of oestrogen receptors in the rat hypothalamus. Neuroendocrinology 4, 289-295.

O'Reilly, P.J. \& DzIUK, P.J. (1973) Change in level of $\mathrm{LH}$ in the sera, and pituitaries of ovariectomized and intact ewes at parturition. Endocrinology 92, 15751578.

Pelletier, J. \& Thimonier, J. (1973) Comparison of the induced preovulatory $\mathrm{LH}$ discharge in lactating and dry sheep during seasonal anoestrus. J. Reprod. Fert. 33, 310-313.

RADFORD, H.M. \& WALLACE, A.L.C. (1971) The effect of testosterone propionate on ovarian activity in sheep. J. Reprod. Fert. 24, 439-440.

RadFoRd, H.M. \& WAllace, A.L.C. (1974) Central nervous blockade of oestradiol-stimulated release of luteinizing hormone in the ewe. J. Endocr. 60, 247252.

Regves, J.J., Arimura, A., Schally, A.V., KraGt, C.L., BeCK, T.W. \& CASEY, J.M. (1972) Effects of synthetic luteinizing hormone-releasing hormone/follicle stimulating hormone-releasing hormone on LH serum, serum FSH and ovulation in anestrous ewes. J. Anim. Sci. 35, 84-89.

RestalL, B.J. (1964) Growth and retrogression of the corpus luteum in the ewe. Aust.J. exp. Agric. Anim. Husb. 4, 274-279.

RESTALL, B.J. (1971) The effect of lamb removal on reproductive activity in Dorset Horn $\times$ Merino ewes after lambing. J. Reprod. Fert. 24, 154, Abstr.

Restall, B.J. \& STARR, B.G. (1977) The influence of season of lambing and lactation on reproductive activity and plasma luteinizing hormone levels in Merino ewes. J. Reprod. Fert. 49, 297-303.

Restall, B.J., RAdFord, H.M. \& Wallace, A.L.C. (1972) Response of lactating ewes to injection of oestradiol benzoate or testosterone propionate. $J$. Reprod. Fert. 28, 164-165.

Restall, B.J., Kearins, R.D., Herdegen, J. \& CaRBERRY, P. (1977) The induction of reproductive activity in lactating ewes. Aust. J. agric. Res. Anim. $H u s b$. (in press).

SAR, M. \& Stumpf, W.E. (1973) Cellular and subcellular localization of radioactivity in the rat pituitary after injection of $1,2-{ }^{3} \mathrm{H}$-testosterone using dry-autoradiography. Endocrinology 92, 631-635.

Symons, A.M., Cunningham, N.F. \& SABA, N. (1974) The gonadotrophic hormone response of anoestrous and cyclic ewes to synthetic luteinizing hormonereleasing hormone. J. Reprod. Fert. 39, 11-21.

White, W.F., Hedlund, M.T., RIPpel, R.H., ARNold, W. \& Flouret, G.R. (1973) Chemical and biological properties of gonadotrophin releasing hormone synthetised by the solid phase method. Endocrinology 93, 96-106.

Received 3 August 1976 